
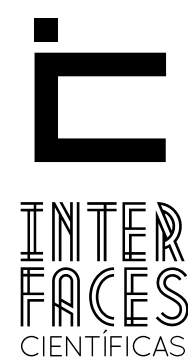

SAÚDE E AMBIENTE

\title{
MATERIAL DE REFERÊNCIA CERTIFICADO PARA QUANTIFICAÇÃO DE DNA: IMPORTÂNCIA FORENSE
}

$$
\text { Rodrigo Grazinoli Garrido' }
$$

\section{RESUMO}

A qualidade nas medições é uma exigência social, de forma que os produtos da Ciência Forense não ficarão de fora desta demanda. Especificamente nas técnicas utilizadas atualmente na Genética Forense, a correta quantificação do DNA é essencial, pois as amostras, em geral são exíguas, deterioradas ou contaminadas com inibidores de PCR. Assim, trabalhar com concentrações desconhecidas, ou não confiáveis, pode acarretar em não obtenção de resultados ou em resultados duvidosos. Para evitar tais problemas, a produção de um Material de Referência Certificado (MRC) nacional para quantificação de DNA faz-se inadiável. Os caminhos para sua obtenção são apresentados neste trabalho.

\section{PALAVRAS-CHAVE:}

Material de Referência Certificado. Reação em Cadeia da Polimerase. Metrologia Forense.
Rodrigo Soares de Moura Neto"

\section{ABSTRACT}

The quality of the measurements is a social requirement, so that the products of Forensic Science will not be left out of this demand. Specifically the techniques currently used in Forensic Genetics, the correct quantification of DNA is essential because the samples are generally confined, deteriorated or contaminated with PCR inhibitors. Thus, working with unknown concentrations, or unreliable, can result in not getting results or unreliable results. To avoid such problems, producing a national Certified Reference Material (CRM) for DNA quantitation becomes imperative. The paths to their attainment are presented in this paper.

\section{KEYWORDS}

Certified Reference Material. Polymerase Chain Reaction. Forensic Metrology. 


\section{RESUMEN}

La calidad de las mediciones es una exigencia social, por lo que los productos de la ciencia forense no se quedarán fuera de esta demanda. Específicamente en relación a las técnicas utilizadas actualmente en genética forense, la correcta cuantificación de ADN es esencial porque las muestras, em general son escasas, deterioradas o contaminadas con inhibidores de PCR. Por lo tanto, trabajar con concentraciones desconocidas o no confiables, puede resultar en no obtener resultados o em la obtención de resultados

\section{INTRODUÇ̃̃̃O}

Medir com qualidade é uma exigência da sociedade. Dessa forma, esta demanda alcança os produtos e serviços relacionados à Ciência Forense, isto é, àqueles relacionados à aplicação de ciências à matéria ou problemas legais, em especial penal. Entre essas ciências, atualmente, apresenta papel de destaque a identificação humana por DNA (GARRIDO; GIOVANELLI, 2011).

As técnicas atuais de biologia molecular utilizadas em identificação humana demandam a prévia determinação da concentração do DNA. Com isso, vários métodos são propostos para a quantificação desse material em uma amostra. Contudo, a grande maioria dos métodos resulta em determinações relativas, com valor vinculado a um calibrante, tomado como padrão (VALLONE et al., 2006; NIELSEN et al, 2008).

Desta forma, emerge a preocupação sobre a validade do material padrão utilizado na calibração e do grau de certeza da quantidade inicial (NIELSEM et al, 2008). Tais questões são especialmente importantes quando se avalia material genético aplicado a questões forenses. Nessa área, os exames são dificulta- dudosos. Para evitar estos problemas, la producción de un Material de Referencia Certificado (MRC) nacional para cuantificación de ADN se convierte en un imperativo. Los caminos hacia su consecución se presentan en este documento.

\section{PALABRAS CLAVE}

MRC; PCR; Metrología Legal. dos em virtude da exiguidade ou da contaminação de amostras, acarretando resultados não confiáveis que podem levar a condenar inocentes ou a inocentar culpados, e por fim, no estabelecimento da justiça (GILBERT, 2010).

A fim de reduzir problemas como estes, o National Institute of Standards and Technology (NIST) dos Estados Unidos já desenvolveu esforços para a certificação de um candidato a material de referência certificado (MRC), específico para quantificação de DNA humano pela PCR. Com o uso de um MRC, é possível avaliar a exatidão e a precisão dos métodos de medição e estabelecer a rastreabilidade metrológica dos resultados (KLINE et al, 2005).

Por meio de uma pesquisa exploratória e qualitativa, desenvolvida por meio de documentação indireta de fontes primárias e secundárias como documentos, livros, artigos e sites, o trabalho buscou sistematizar o conhecimento sobre quantificação de DNA, mostrando a importância social da fidedigna determinação das concentrações a partir da produção nacional e uso de um MRC. 


\section{QUANTIFICAÇÃO DO DNA}

A análise de material genético, com técnicas modernas de biologia molecular, requer primeiramente a determinação da sua concentração. Atualmente vários são os métodos utilizados para a quantificação de material genético em uma amostra. São exemplos de métodos medição da absorbância a $260 \mathrm{~nm}$ com o uso de um espectrofotômetro, a emissão a $458 \mathrm{~nm}$ na presença de Hoechst 33258 em fluorímetro ou através da fluorescência emitida lida com um transiluminador após indução por UV em ácido nucléico intercalado com brometo de etídio (SAMBROK; RUSSEL, 2001). Todavia, uma das ferramentas mais utilizadas em laboratórios médicos e forenses é a Reação em Cadeia da Polimerase quantitativa em tempo real (qPCR). Uma grande variedade de métodos de qPCR foram desenvolvidos nos últimos anos, especialmente para uso em amostras forenses (KLINE et al.(a), 2005).

De forma curiosa, a grande maioria dos métodos de quantificação produz resultados relativos, com valor relacionado a um calibrante, tomado como padrão (VALLONE et al., 2006). Com isso, surge a preocupação sobre a validade do material padrão utilizado para a calibração e do grau de certeza nessa quantidade inicial (NIELSEM et al, 2008).
Uma correta quantificação do material genético humano é essencial em amostras forenses que, em geral são exíguas, deterioradas e contaminadas com inibidores de PCR. A exatidão na quantificação da amostra é também requisito essencial para as técnicas posteriores à extração, onde se determina o perfil genético. De forma bastante generalizada, uma das técnicas que os laboratórios forenses lançam mão é a amplificação do DNA por meio de PCR com múltiplos marcadores de Short Tandem Repeat (STR) (BUTLER, 2010) para posterior separação por meio de eletroforese capilar e análise.

No caso de quantidades de DNA acima das requisitadas pela técnica, em torno de $2 \mathrm{ng} / \mathrm{l}$, é comum observar desbalanço entre loci, picos fora da escala ou alargados e bífidos (Figura 1A). Por outro lado, ao trabalhar com concentrações abaixo das ideais, menores que $0,1 \mathrm{ng} / \mathrm{l}$, podem prevalecer amplificações estocásticas, com perda de alelo - "allele dropout" (BUTLER, 2010) (Figura 1B). Em geral, têm-se como resultados o desbalanceamento entre loci e entre alelos em heterozigose e a anulação de alelos (Figura 2), simulando homozigoses, e com reprodutividade baixíssima (SAMBROK; RUSSEL, 2001).

Figura 1: Exemplo de picos alargados e bífidos (A) e amplificações estocásticas, com perda de alelo, “dropout”(B - marcação em vermelho) (modificado de VALLONE et al, 2006)

A

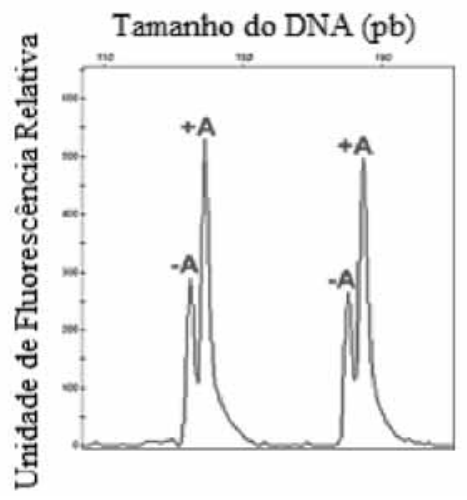

B

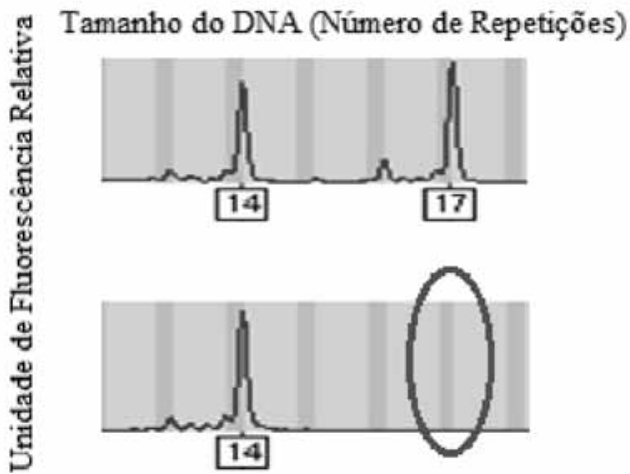




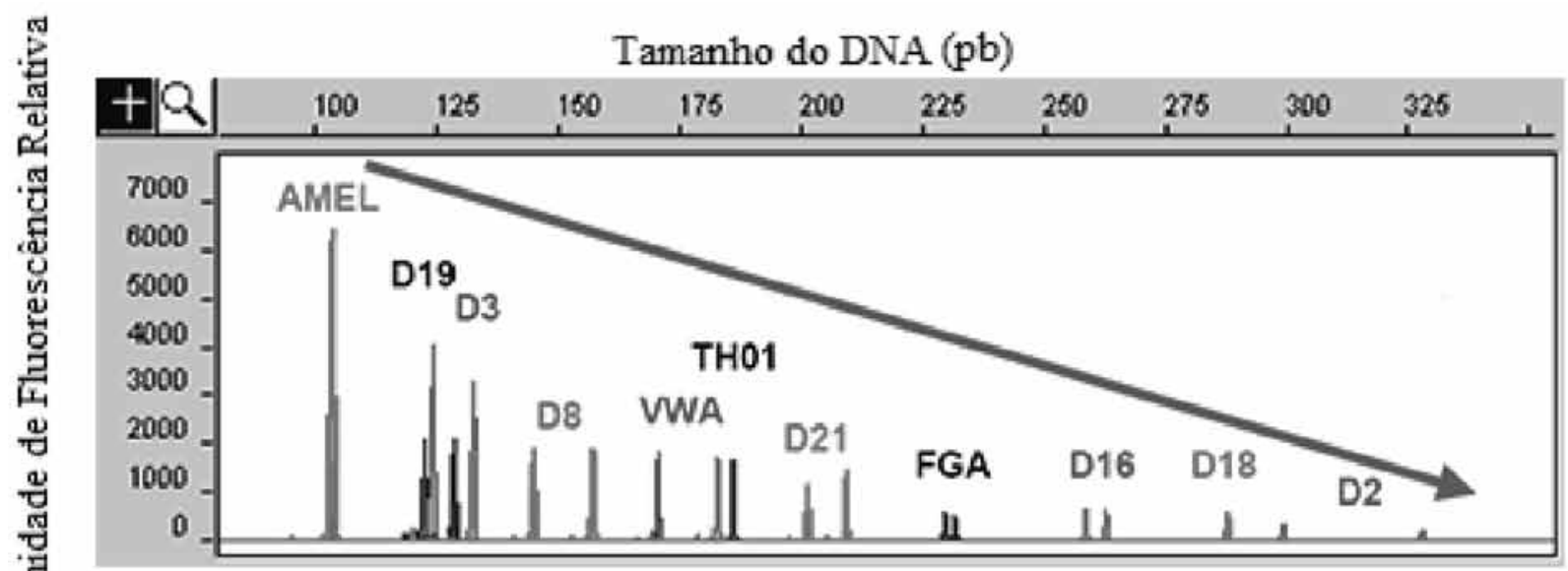

Outra questão que vem sendo amplamente discutida é a utilização indiscriminada da análise de DNA a partir de evidências criminais quantitativamente menores (GILBERT, 2010). Há casos em que a quantificação do DNA presente na amostra não é possível, mas ainda sim são obtidos perfis aumentando o número de ciclos de PCR. Como descrito, esses perfis também estariam sujeitos aos artefatos das baixas concentrações de DNA. Apenas no Reino Unido, a análise de baixo número de cópias já foi utilizada em mais de 21 mil casos criminais desde o fim da década de 90 . Em todos estes casos, resultados duvidosos foram gerados.

\section{MATERIAL DE REFERÊNCIA CERTIFICADO [MRC]}

Para minimizar os problemas decorrentes do processo de quantificação de DNA, o National Institute of Standards and Technology (NIST) dos Estados Unidos, coordenou um ensaio interlaboratorial para avaliar a exatidão da quantificação de DNA empregando diversas ferramentas (KLINE et al., 2005). Os resultados desse estudo serviram como base para o processo de validação de um candidato a material de referência certificado (MRC), específico para quantificação de DNA humano pela PCR (KLINE et al., 2009).

Para tanto, Kline et al. (2009) varreram através de espectrofotômetro as amostras em cinco comprimento de onda $(230,260,270,280$ e $330 \mathrm{~nm})$ a fim de determinar contaminantes orgânicos, como fenóis e tiocianato, protéicos e, a molécula de interesse, DNA (Figura 3). Com isso, foi possível estabelecer uma relação entre a variação na densidade óptica (DO) e a concentração de DNA (Tabela 1). Assim, a partir de amostras de doadores voluntários e de DNA comercial, foi produzido, caracterizado e disponibilizado o MRC 2372 na forma de 3 componentes, uma fonte de DNA masculina, uma fonte feminina e uma mistura (KLINE et al., 2009). 
Figura 3: Variação da densidade óptica em varredura espectral em amostra de DNA (modificado de KLINE et al, 2009).

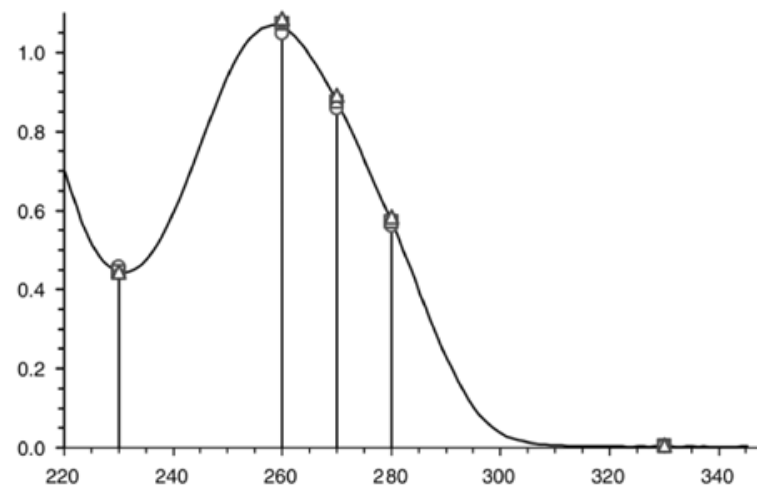

Tabela 1: Concentração de DNA para uma unidade na densidade óptica de 260nm (caminho óptico de $1 \mathrm{~cm}$ ) (KLINE et al., 2009).

\section{DNA}

$\approx 50 \mathrm{ug} / \mathrm{ml}$ DNA fita dupla

$\approx 40 \mathrm{ug} / \mathrm{ml}$ DNA fita simples

$\approx 33 \mathrm{ug} / \mathrm{ml}$ oligonucleotídeos

0 uso de um MRC permite ao técnico avaliar a exatidão e a precisão do seu método de medição e estabelecer a rastreabilidade metrológica dos resultados (ABNT, 2002). Um material de referência é todo material suficientemente homogêneo e estável em relação a uma ou mais propriedades específicas de interesse, produzido para se adequar a uma utilização pretendida em uma medição ou em um exame de propriedades qualitativas (VIM, 2009). Já o material de referência certificado, deve ainda vir acompanhado de uma do- cumentação emitida por um organismo com autoridade, que fornece os valores de medição das propriedades especificadas, suas incertezas e a rastreabilidade metrológica associada utilizando procedimentos de medição válidos.

A rastreabilidade metrológica requerida para um MRC guarda relação com a propriedade de um resultado de medição, que permite a relação a uma referência através de uma cadeia ininterrupta e documentada de calibrações, cada uma contribuindo para a incerteza de medição (VIM, 2009). Para que as medições sejam rastreáveis é preciso conectar qualquer material de referência ao Sistema Internacional de Unidades (SI). Isto é, no caso de uma solução medida pelo método gravimétrico, só é possível comparar resultados obtidos, caso a balança, as massas e padrões utilizados sejam rastreáveis ao valor de uma unidade comum, neste caso o protótipo internacional do quilograma, padrão primário de medição para massa (CAIXEIRO, 2010). Em resumo, esta propriedade não está relacionada ao método, ao material, a um equipamento ou a uma instituição, mas um valor (DE BIĖVRE, 2000).

Para produzir e certificar um candidato a MRC é necessário um longo período de estudo, onde se busca caracterizar o material e determinar a homogeneidade e a estabilidade do mesmo. A estabilidade, por exemplo, deve ser avaliada em estudos de curta duração, visando determinar as condições de transporte, e longa duração, para simular as condições de armazenamento (ISO, 2005). Durante o processo, exercícios interlaboratoriais podem ser requeridos (KLINE et al., 2005; KLINE et al., 2009; KLINE et al., 2010).

\section{CONSIDERACCÕES FINAIS}

Na verdade, a qualidade nas medições obtidas em diversas áreas que afetam o nosso dia a dia é uma exigência social. No caso das ciências forenses, apesar do papel fundamental e do grande impacto dos seus resultados em nossas vidas, apenas recentemente pode-se observar preocupação genuína com a precisão e exatidão das medidas obtidas. Embora grande parte das análises forenses seja de natureza qualitativa, 
muitas vezes medidas quantitativas em etapas prévias são necessárias para garantir a qualidade dos resultados obtidos. Especialmente na área de DNA forense, cujo alto poder de individualização é suficiente para garantir seu valor probante, o rigor profissional deve ser ainda maior na obtenção de resultados.

\section{REFERÊNCIAS}

ABNT ISO Guia 33. Utilização de Materiais de Referência Certificados, 2002.

BUTLER, J. M. Fundamentals of Forensic DNA Typing. Academic Press, 2010.

CAIXEIRO, J. M. R. Produção e Certificação de Materiais de Referência. Apostila de Treinamento. Dimci/ Dquim-Inmetro, 2010

DE BIĖVRE, P. Traceability of (values carried by) reference materials. ACQUAL, 5, p.224-230, 2000.

GIOVANELLI, A.; GARRIDO, R. G. A Perícia Criminal no Brasil como Instância Legitimadora de Práticas Policiais Inquisitoriais. Revista LEVS, v. 7, p.5-24, 2011.

GILBERT, N. DNA's Identity Crisis. Nature, v. 44, p. 347-348, 2010.

ISO GUIDE 35. Reference materials - General and statistical principles for certification, 2006.

KLINE, M.C. et al. Results from NIST 2004 DNA Quantification Study. J. Forensic Sci., 50 (3), p.571-578, 2005.
Assim, a produção e certificação do MRC nacional para quantificação de DNA não pode mais aguardar. Tal iniciativa tem sido desenvolvida pelo grupo de Metrologia Forense da Divisão de Projetos do Instituto Nacional de Metrologia, Normalização e Qualidade Industrial (Inmetro).

KLINE, M.C. et al.(a) Testing candidate DNA quantitation standards with several real-time quantitative PCR methods. [16th International Symposium on Human Identification, 2005], Disponível em: <www.promega.com/geneticidproc/ussymp16proc/abstracts/ kline.pdf> Acesso em 14 dez. de 2010.

KLINE, M.C. et al. Production and certification of NIST Standard Reference Material 2372 Human DNA Quantification Standard. Anal. Bioanal. Chem., v. 394, p.1183-1192, 2009.

NIELSEN, K. et al. Comparison of five DNA quantification methods. Forensic Sci. Int. Genet., v. 2, n. 3, p. 226-230, 2008.

SAMBROK, J.; RUSSEL, D.W. Molecular Cloning: A Laboratory Manual, 3. ed., Cold Spring Harbor Laboratory Press, 2001.

VALLONE, P.M. et al. Examining Candidate DNA Quantification Standards with Real-Time Quantitative PCR assays. 58th Annual AAFS Meeting, Seatle, WA, 2006.

VOCABULÁRIO INTERNACIONAL de METROLOGIA (VIM) - Conceitos Fundamentais e Gerais de Termos Associados. Inmetro, 2009. 

IB/UFRJ. 
